\title{
Experimental assessment of temperature increase and presence of predator carcass changing the response of invertebrate shredders
}

\author{
Fernanda Keley Silva Pereira Navarro ${ }^{1,3}$, Renan de Souza Rezende ${ }^{2}$ \& \\ José Francisco Gonçalves Júnior ${ }^{1}$ \\ ${ }^{1}$ Departament of Ecology, University of Brasilia - UnB, Campus Darcy Ribeiro - North Wing, \\ CEP 70910-900, Brasilia, DF, Brazil \\ ${ }^{2}$ Departament of Ecology and Zoology, Federal University of Santa Catarina - UFSC, \\ Campus Universitário Reitor João David Ferreira Lima - Trindade, \\ CEP 88040-970, Florianópolis, SC, Brazil \\ ${ }^{3}$ Corresponding author: Fernanda Navarro, e-mail: fbionavarro@gmail.com
}

NAVARRO, F.K.S.P., REZENDE, R.S. \& GONÇALVES, J.F.Jr. Experimental assessment of temperature increase and presence of predator carcass changing the response of invertebrate shredders. Biota Neotrop. 13(4): http://www.biotaneotropica.org.br/v13n4/en/abstract?article+bn00313042013

\begin{abstract}
The role of the invertebrate shredders in leaf decomposition process in tropical lotic ecosystems has been explored only recently. In addition to the influence of the quality of litter and the temperature, the risk of predation generally results in changes on the survival and behavior of invertebrate shredders. The aim of this study was to observe the responses of the invertebrate shredders to different species of leaf litters (Experiment 1: Talauma ovata and Inga laurina; Experiment 2:Talauma ovata, Inga laurina and Richeria grandis ) under gradual temperature rise $\left(24^{\circ} \mathrm{C}, 26^{\circ} \mathrm{C}, 28^{\circ} \mathrm{C}, 30^{\circ} \mathrm{C}, 32^{\circ} \mathrm{C}\right.$ ), in the presence (Experiment 2) and absence (Experiment1) of fish (Astyanax sp.) carcasses, as well as to observe the possible consequences of the leaf mass loss (LML). The results from the first experiment suggest that the quality of the litter was capable of changing the feeding preference of the invertebrate shredders, regardless of temperature. In the second experiment, the leaf mass loss was faster in litter with higher quality (Talauma ovate and Richeria grandis ); in addition, we observed that the exploration of these resources resulted in the case-building in the presence of fish carcass. The negative correlation of leaf mass loss of Inga laurina in relation to temperature in the presence of fish carcass probably occurred due to an accelerated metabolic, respiratory and cardiac rates. Apparently, this process may have led to an increased shredding activity on the litters of better quality in relation to the Inga laurina. This fact may be related to less energy consumption, so as to meet their energy demands more efficiently.
\end{abstract}

Keywords: feeding activity, global warming, decomposition.

NAVARRO, F.K.S.P., REZENDE, R.S. \& GONÇALVES, J.F.Jr. Avaliação experimental de elevação da temperatura e a presença de carcaça do predador alterando a resposta de invertebrados fragmentadores. Biota Neotrop. 13(4): http://www.biotaneotropica.org.br/v13n4/pt/abstract?article+bn00313042013

Resumo: O papel dos invertebrados fragmentadores no processo de decomposição foliar em ecossistemas lóticos tropicais vem sendo recentemente explorado. Além da influência da qualidade do detrito e da temperatura, o risco de predação geralmente implica alterações sobre a sobrevivência e comportamento de invertebrados fragmentadores. O objetivo deste estudo foi verificar as respostas dos invertebrados fragmentadores a diferentes espécies de detritos foliares (Experimento 1: Talauma ovata e Inga laurina; Experimento 2: Talauma ovata, Inga laurina e Richeria grandis) sob elevações graduais de temperatura $\left(24^{\circ} \mathrm{C}, 26^{\circ} \mathrm{C}, 28{ }^{\circ} \mathrm{C}, 30^{\circ} \mathrm{C}, 32^{\circ} \mathrm{C}\right)$, na presença (Experimento 2) e ausência (Experimento1) de carcaças de peixes (Astyanax sp.), assim como verificar as possíveis consequências sobre a perda de massa foliar (PMF). Os resultados do primeiro experimento sugerem que a qualidade do detrito foi capaz de alterar a preferência alimentar dos invertebrados fragmentadores, independe da temperatura. No segundo experimento, a perda de massa foliar foi maior sobre detritos de melhor qualidade (Talauma ovata e Richeria grandis), além disso, foi verificada a exploração destes recursos para a construção de casulos, na presença de carcaça de peixe. A correlação negativa da perda de massa foliar da espécie Inga laurina em função da temperatura na presença de carcaça de peixes, provavelmente ocorreu devido a uma aceleração da taxa metabólica, respiratória e cardíaca. Isto pode ter levado a uma ampliação da atividade de fragmentação sobre os detritos de melhor qualidade em relação ao Inga laurina, a fim de atender suas demandas energéticas com maior eficiência e menor gasto energético.

Palavras-chave: atividade de alimentação, aquecimento global, decomposição. 


\section{Introduction}

In lotic systems, with well-developed marginal vegetation and reduced light penetration, the main source of energy for the metabolism derives from organic matter of allochthonous origin, characterizing them as heterotrophic (Wallace et al. 1997, Gessner et al. 2010). In these environments, allochthonous leaf litter is decomposed by a combination of physical, chemical and biological factors (Hagen et al. 2006). Thus, the decomposition is influenced by characteristics intrinsic to aquatic environments, such as flow, $\mathrm{pH}$ (Gessner \& Chauvet 2002), water temperature (Liski et al. 2003), chemical composition of detritus (Suberkropp \& Chauvet 1995, Ostrofsky 1997) and biomass and the abundance of decomposers and shredded invertebrate (Miyashita \& Niwa 2006). Therefore, the health and functioning of lotic ecosystems may be influenced by natural or anthropic changes in the adjacent terrestrial systems and in the biogeochemical cycles in local, regional or even global scale (Tabacchi et al. 1998, Chapin III et al. 2002).

Anthropic actions (e.g. agriculture, cattle raising, urban development, use of fossil fuels and deforestation) have led to an intensification of the greenhouse effect, followed by an accelerated hydrological cycle, which contribute even more to the enhanced global warming effect (Chapin III et al. 2002). Some studies estimate that the average temperature of the planet may rise between $1.8^{\circ} \mathrm{C}$ and $4{ }^{\circ} \mathrm{C}$ by 2100 , thus leading to an increase in the temperatures of the rivers (Houghton et al. 2001, Intergovernmental... 2007). This increase in the temperature may result in serious consequences, such as physiological changes of several organisms, extinction of species, biological interactions and ecological processes (Mooney et al. 2009). Ectothermic animals are strongly influenced by the environmental conditions, where the effects of the temperature have been documented for several taxa (Woods et al. 2003). However, the influence of temperature on the exploration of leaf resources by invertebrate shredders and the probable consequences within the nutrient cycling have been seldom analyzed (Villanueva et al. 2011).

Some works have analyzed the effect of the temperature on the decomposition of allochthonous litter and its consequence for the functioning of lotic ecosystems (Boyero et al. 2011). Ex-situ studies showed that the water temperature directly affects the decomposition, by promoting the leaching of soluble compounds (Chergui \& Pattee 1990), and indirectly through the increased microbial activity (Carpenter \& Adams 1979), thus stimulating leaf consumption by invertebrate shredders (González \& Graça 2003, AzevedoPereira et al. 2006). The increased temperature affects mainly the detritivorous submitted to low quality litter, thus interfering in the $\mathrm{N}: \mathrm{P}$ ratio of the excreta (Villanueva et al. 2011).

The role of these invertebrate shredders in leaf breakdown in tropical lotic ecosystems has been explored recently (Wright \& Covich 2005, Gonçalves Junior et al. 2006, Wantzen \& Wagner 2006), indicating the leaves may provide both food and habitat (Ruetz III et al.2006, Leroy \& Marks 2006, Moretti et al. 2009, Gonçalves Junior et al. 2012). The chemical composition of the leaf influences the selection of plant species by the invertebrate as resource or shelter (Wright \& Covich 2005, Graça et al. 2001, Gonçalves Junior et al. 2006). However, the studies are still not sufficient to help understand the interaction mechanisms between the invertebrate shredders, quality of the litter and temperature in headwater streams.

In addition to the influence of the availability and quality of the litter, some studies have showed the negative influence of predators on the survival and behavior of invertebrate shredders (Konishi et al. 2001, Ruetz et al. 2002). In aquatic ecosystems, this predator-prey interaction may be shown through chemical substances that are released by the organisms (Brönmark \& Hansson 2000, Ruther et al.
2002). These are capable of mediating a series of other interactions, leading to a change in the individuals' behavior, in the exploration of the resources, which may result in the reduction of the decay rate (Brönmark \& Hansson 2000, Ruther et al. 2002). However, the invertebrate shredders are rare in tropical systems (Boyero et al. 2011). The genus Phylloicus has been regarded as the most common shredder among those that comprise this trophic group, and thus it can be used in studies that analyze its effect on leaf detritus (Moretti 2005). Thus, modifications either in terms of biomass, abundance or nutritional value of some of the organisms present in the food web (plant-herbivore-predator) may reflect changes in trophic levels interlinked and hence the energy flow and nutrient cycling in aquatic environments (Wallace et al. 1997, Miyashita \& Niwa 2006).

The genus Phylloicus Muller, 1880, (Calamoceratidae), has 61 known species, and these are distributed from South to Central America, being very diverse in Brazil, Peru and Venezuela (Huamantinco et al. 2005, Prather 2003). Phylloicus larvae are generally found among underwater leaves in lotic environments, and this leaf resource is used as food and raw material to dorsoventrally case-building (Wantzen \& Wagner 2006, Wiggins 1996).

In view of this context, the aims of this study were (i) to analyze the consumption of the invertebrate shredders (genus Phylloicus) of chemically different leaf litters under different temperature levels, and (ii) to study the predation effect on the consumption of Phylloicus, using the presence and absence of fish carcasses. Three hypotheses are observed: (1) The Phylloicus sp. larvae will be capable of accelerating the leaf mass loss of all kinds of litter in higher temperatures (Experiment 1); (2) High quality leaf litters will be more easily degraded by the invertebrate in all levels of temperature (Experiments 1 and 2); (3) The presence of the Predator's carcass will be capable of reducing the leaf mass loss of all kinds of litter in the different levels of temperature, through top-down control in the litter chain (Experiment 2).

\section{Material and Methods}

\section{Collection procedures}

The genus Phylloicus (Trichoptera) was the invertebrate shredder used in this study. These organisms were collected by "active

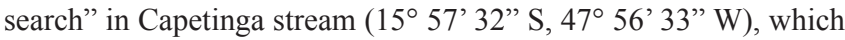
is situated in Água Limpa Farm (area of 4,500 hectare), belonging to the University of Brasília. The invertebrate were taken to the laboratory in insulated boxes. In the laboratory, the invertebrate with leaf case-building were kept for 24 hours in 60-L tanks with water and riverbed gravel from the same stream. The tanks were continuously aired during this period.

\section{Experimental procedures}

\subsection{Experiment 1}

This experiment was carried out in order to test the responses of the invertebrate shredders facing a categorical variable (temperature) in the presence of difference types of leaf litter. The experiment comprised five treatments that differed only in water temperature: Treatment $1: 24^{\circ} \mathrm{C}$, Treatment $2: 26^{\circ} \mathrm{C}$, Treatment $3: 28^{\circ} \mathrm{C}$, Treatment 4:30 ${ }^{\circ} \mathrm{C}$ and Treatment $5: 32^{\circ} \mathrm{C}$. In each 60 -L tank three invertebrate were put without the leaf case-building and five leaf discs of each kind of plant species (Talauma ovata St. Hill. and Inga laurina Sw. Willd). The temperatures of each tank were kept through automatic thermostats and oxygenation was kept by aerators. In addition, a submersible pump was used in each tank to simulate the lotic flow present in the natural environment. 


\subsection{Experiment 2}

This experiment was carried out in order to test the responses of the invertebrate shredders facing the interaction of two categorical variables (temperature and fish carcass) in the presence of difference types of leaf litter. The experiment also comprised five treatments that differed only in the water temperature: Treatment $1: 24^{\circ} \mathrm{C}$, Treatment 2:26 ${ }^{\circ} \mathrm{C}$, Treatment $3: 28^{\circ} \mathrm{C}$, Treatment $4: 30{ }^{\circ} \mathrm{C}$ and Treatment $5: 32^{\circ} \mathrm{C}$. In each tank two invertebrate were put without the leaf case-building, five leaf discs of each plant species (Talauma ovata St. Hill. , Inga laurina Sw. Willd and Richeria grandis Vahl) and one Astyanax sp. Baird \& Girard, 1854, fish carcass. These fish are characterized for being invertivorous, and for presenting Phylloicus sp. in their diet (G.F.M. Leite, unpublished data). The temperatures of each tank were kept through automatic thermostats and oxygenation was kept by aerators.

\section{Leaf mass loss}

Discs were taken of wet leaf discs (diameter $1.8 \mathrm{~cm}$ ) and after were air weighed on precision balance $(0.00001 \mathrm{~g})$. They were distributed homogeneously among all treatments in both experiments. These discs were fixed in the tank substrate with pins of different colors in order to enable their identification. Leaf discs homologous (similar used in the experiments) were dried in oven at $62{ }^{\circ} \mathrm{C}$ for 48 hours for correction between air $\mathrm{x}$ dry weight (to estimate initial dry weight).

The incubation period of the leaf discs related to each treatment in the tanks was 11 days in both experiments. After this period, they were put in oven at $62{ }^{\circ} \mathrm{C}$ for 48 hours and further weighed to measure the final dry weight. The leaf mass loss (LML) between the different substrates of each treatment was measured observing the difference between the initial dry weight and the final dry weight. Both experiments were carried out at the experimental unit of the limnology laboratory, Department of Ecology of the University of Brasília (UnB).

\section{Characterization of plant species}

In order to measure the hardness of each plant species, leaf discs (diameter $1.8 \mathrm{~cm}$ ) were cut, avoiding their central ribs and, after moistening them to restore their original characteristics, necessary force to perforate the leaf blade was applied through a $0.79-\mathrm{mm}$ piston (Graça \& Zimmer 2005). Total polyphenols were measured for each plant species studied, as proposed by Bärlocher \& Graça (2005). Lignin and cellulose analyses were quantified according to Gessner (2005).

\section{Statistical analysis}

Data normality was tested according to Kolmogorov-Smirnov (Massey Junior 1951) and, when required, transformed using the neperian logarithm (Ln). Then the Student's t-test was used to analyze the percentage of mass loss of Inga laurina and Talauma ovata by invertebrate action of the genus Phylloicus (dependent variable) in experiment 1 , and among the different temperatures studied (categorical variable) (Zar 1996). In experiment 2, the percentage of mass loss of Richeria sp., Inga laurina and Talauma ovata by invertebrate of genus Phylloicus (dependent variable) was tested through ANOVA (one-way) in the different temperatures associated to fish carcass (categorical variable). We used Tukey test for discrimination among the categorical variables (Zar 1996). The Student's t-test was also used to test whether there was significant difference in the percentage of mass of the litter (dependent variable) between the two experiments carried out (categorical variable).
The relationship of temperature (experiment 1) and the temperature associated to fish carcass (experiment 2) with the percentages of mass loss by invertebrate of genus Phylloicus was tested through Pearson's coefficient ( $\rho$; ranges from -1 to 1 ), considering $\mathrm{p}<0.05$. The values equal or superior to 0.70 indicate a strong; from 0.30 to 0.7 indicates mild, and from 0 to 0.30 a weak correlation. Moreover, they may be positive (the variables increase or decrease together) or negative (means that the variables vary in opposite direction; Press et al.1992).

\section{Results}

The chemical characterization of litter of Talauma ovata presented the lowest concentrations of polyphenols, hardness and lignin in relation to the other litters. Richeria grandis presented higher concentrations of polyphenols and hardness, while Inga laurina presented the highest values in percentage of lignin and cellulose (Table 1).

\section{Experiment 1 (without fish)}

The percentages of mass loss of Inga laurina and Talauma ovata leaf discs by invertebrate action of genus Phylloicus were different among the litter in all temperatures tested, with the highest values observed in Talauma ovata in all treatments when compared to Inga laurina (Table 2; Figure 1).After relating the percentages of mass loss of litters of Inga laurina (Pearson's Correlation, $\rho=-0.1, p=0.518$ ) and Talauma ovata (Pearson's Correlation, $\rho=-0.4, p=0.057$ ) to the increase of temperature in the experiment, we did not find significant correlation.

\section{Experiment 2 (with fish)}

The mass loss between the litters of Inga laurina, Richeria grandis, and Talauma ovata submitted to action by Phylloicus was different in all treatments (Table 3). Richeria grandis and Talauma ovata were not different in their mass losses (Tukey, $\mathrm{p}<0.05$ ). On the other hand, Inga laurina presented the lowest values (Tukey, $\mathrm{p}<$ 0.05; Figure 2). We found mass loss of litters by Phylloicus sp. with increased temperature in the presence of fish carcasses. However, we observed that Inga laurina was negative correlated (Pearson's Correlation, $\rho=-0.7, p=0.023)$, but we did not find correlation to Richeria grandis (Pearson's Correlation, $\rho=-0.1, p=0.483$ ) and Talauma ovata (Pearson's Correlation, $\rho=0.1, \mathrm{p}=0.834$ ).

\section{Experiment 1 (without fish) X Experiment 2 (with fish)}

The percentages of mass loss by invertebrate of genus Phylloicus between the two treatments carried out with litter of Inga laurina and Talauma ovata were significantly different in most of the temperatures analyzed (Table 2). Talauma ovata presented higher significant values in treatment 2 (with fish) when compared to treatment 1 (without fish) for all treatments. However, Inga laurina did not presented significant difference in temperatures of $24{ }^{\circ} \mathrm{C}$ and $30{ }^{\circ} \mathrm{C}$, contrary to the other one $\left(26^{\circ} \mathrm{C}, 28^{\circ} \mathrm{C}\right.$ and $\left.32^{\circ} \mathrm{C}\right)$. Except for $24^{\circ} \mathrm{C}$ in Inga laurina presented the highest values of leaf mass loss in Experiment 1 (without fish) when compared to 2 (with fish).

Table 1. Characterization of plants species: Concentration of polyphenols $\left(\% \mathrm{~g}^{-1}\right.$ dry mass), Hardness $(\mathrm{g})$, Lignin $\left(\% \mathrm{~g}^{-1}\right.$ dry mass) and Cellulose $\left(\% \mathrm{~g}^{-1}\right.$ dry mass).

\begin{tabular}{lcccc}
\hline \multicolumn{1}{c}{ Plant Species } & Polyphenols & Hardness & Lignin & Cellulose \\
\hline Richeria grandis & 6.95 & 400.1 & 28.92 & 20.84 \\
Talauma ovata & 2.21 & 149.75 & 22.93 & 28.04 \\
Inga laurina & 4.79 & 363.75 & 43.56 & 29.11 \\
\hline
\end{tabular}


Effect of temperature and Predation on response of shredders

Table 2. Student's t-test and $\mathrm{p}$ values for mass loss rate for Inga laurina and Talauma ovata in the experiment 1 (absence of fish carcass) and between experiments 1 (absence of fish carcass) and 2 (presence of fish carcass), in different temperature gradients.

\begin{tabular}{|c|c|c|c|c|c|c|}
\hline & \multirow{2}{*}{\multicolumn{2}{|c|}{$\begin{array}{c}\text { Experiment } 1 \\
\text { T. ouvata } \times \text { I. laurina }\end{array}$}} & \multicolumn{4}{|c|}{ Experiment $1 \times$ Experiment 2} \\
\hline & & & \multicolumn{2}{|c|}{ T. ovata } & \multicolumn{2}{|c|}{ I. laurina } \\
\hline & $\mathbf{t}$ & $\mathbf{p}$ & $\mathbf{t}$ & $\mathbf{p}$ & $\mathbf{t}$ & $\mathbf{p}$ \\
\hline $24^{\circ} \mathrm{C}$ & 3.97 & 0.0032 & 24.67 & $<0.001$ & 1.839 & 0.099 \\
\hline $26^{\circ} \mathrm{C}$ & 3.58 & 0.0059 & 4.904 & $<0.001$ & 3.303 & 0.009 \\
\hline $28^{\circ} \mathrm{C}$ & 3.48 & 0.0068 & 7.117 & $<0.001$ & 9.613 & $<0.001$ \\
\hline $30{ }^{\circ} \mathrm{C}$ & 4.18 & 0.0023 & 19.49 & $<0.001$ & 1.990 & 0.077 \\
\hline $32{ }^{\circ} \mathrm{C}$ & 3.91 & 0.0035 & 13.68 & $<0.001$ & 4.015 & 0.003 \\
\hline
\end{tabular}

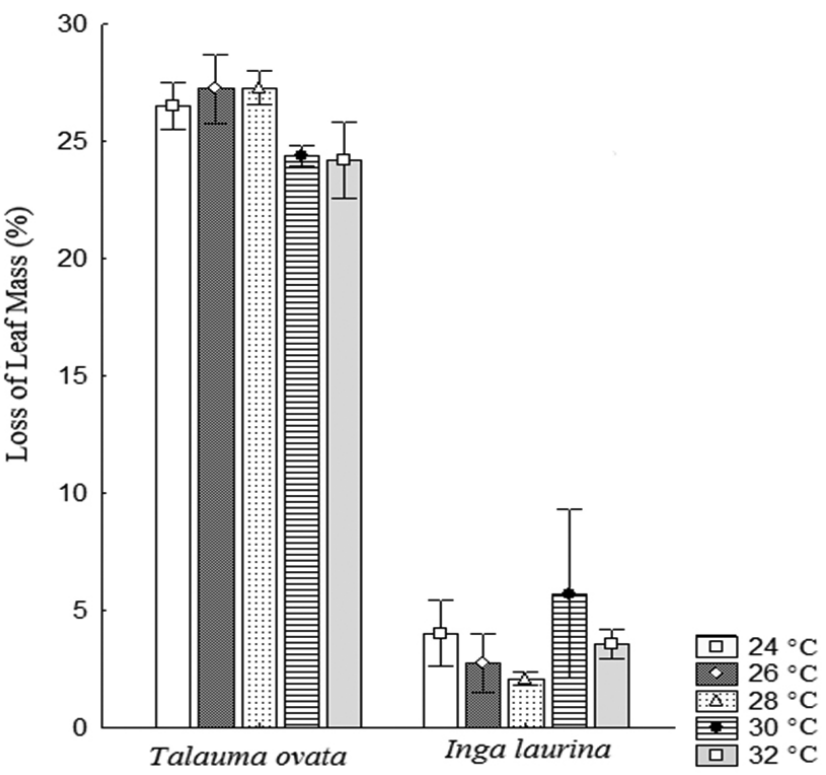

Figure 1. Average values and standard errors of the percentages of mass loss by invertebrate of genus Phylloicus of Inga laurina and Talauma ovata in the different temperatures studied $\left(24^{\circ} \mathrm{C}, 26^{\circ} \mathrm{C}, 28^{\circ} \mathrm{C}, 30^{\circ} \mathrm{C}\right.$ and $\left.32{ }^{\circ} \mathrm{C}\right)$.

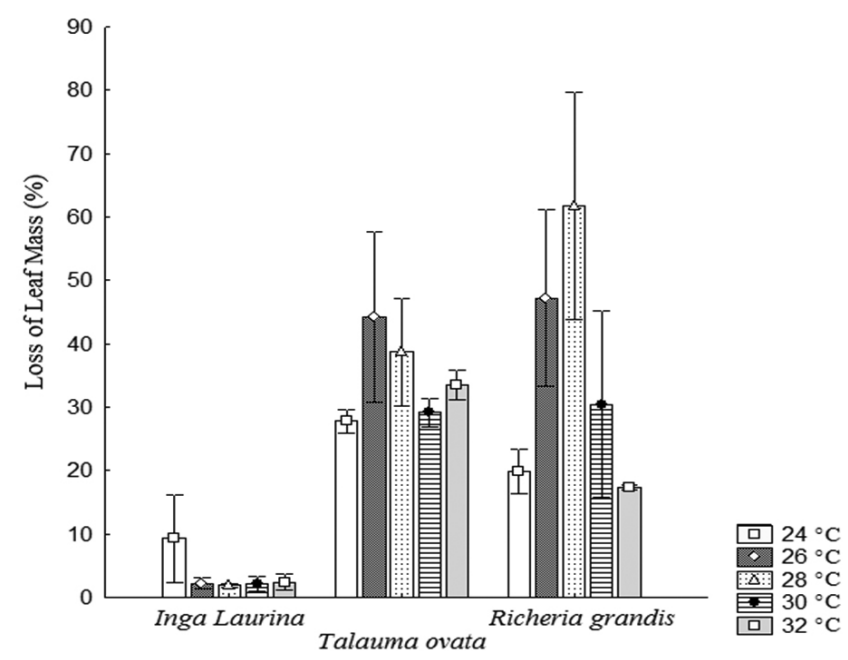

Figure 2. Average values and standard errors of the percentages of mass loss by invertebrate of genus Phylloicus of Richeria grandis, Inga laurina and Talauma ovata in the different temperatures studied $\left(24^{\circ} \mathrm{C}, 26^{\circ} \mathrm{C}, 28^{\circ} \mathrm{C}\right.$, $30^{\circ} \mathrm{C}$ and $32{ }^{\circ} \mathrm{C}$ ).
Table 3. Significance (p) values for ANOVA (one-way) test, degrees of freedom (DF) used and residual DF in the analysis, as well as F-test deviance values for mass loss between Richeria grandis, Inga laurina and Talauma ovata in different temperature gradients in the presence of fish carcass.

\begin{tabular}{ccccc}
\hline & DF & Residual DF & Deviance (F) & $\mathbf{p}$ \\
\hline $24^{\circ} \mathrm{C}$ & 2 & 12 & 7.13 & 0.009 \\
$26^{\circ} \mathrm{C}$ & 2 & 12 & 23.77 & $<0.001$ \\
$28^{\circ} \mathrm{C}$ & 2 & 12 & 40.55 & $<0.001$ \\
$30^{\circ} \mathrm{C}$ & 2 & 12 & 17.78 & 0.002 \\
$32^{\circ} \mathrm{C}$ & 2 & 12 & 21.65 & $<0.001$ \\
\hline
\end{tabular}

\section{Discussion}

\section{Shredding activity $\times$ Quality of leaf litter}

The results of the first experiment indicated that the quality of the litter was capable of changing the feeding preference of the invertebrate shredders. A better quality of the Talauma ovata leaves could be explained by lower concentrations of secondary compounds, lignin and cellulose facilitating the consume by the Phylloicus larvae. These results are according to Graça et al. (2001) who observed a feeding preference of Phylloicus for leaves with high $\mathrm{N}$ and $\mathrm{P}$, and lower polyphenols and lignin (Ficus) content, thus avoiding litter with lower $\mathrm{N}$ and $\mathrm{P}$ content, and high polyphenols and lignin (Anacardium) content. Another important aspect is that, when synthesizing large quantities of secondary compounds (polyphenols), many tropical species impair the microbial colonization, thus reducing the palatability of leaves for the shredders (Coley \& Aide 1991, Gessner \& Chauvet 1994).

In the second experiment, the invertebrate also had a higher feeding preference for Talauma ovate and for Richeria grandis in relation to Inga laurina. However, Richeria grandis did not present different concentrations of polyphenols and hardness in relation to Inga Laurina, probably because they showed lower lignin and cellulose contents. This may suggest that the feeding preference of the Phylloicus sp. under risk of predation due the low percentage of structural compounds (lignin and cellulose) leading to easy obtain energy. Ratnarajah \& Barmuta (2009) observed that the hardness of leaves did not affect the consumption of the litters by Antipode wellingtoni and Caenotaplicata, corroborating our results, where the structural composition of the leaves was the main factor for the increase of leaf consumption, regardless of hardness.

\section{Shredding behavior $\times$ Temperature gradient}

The absence of significant correlation between the leaf mass loss of litter of Inga laurina or Talauma ovata with the different temperature gradients suggests that the increased temperature was 
not capable of increasing the consumption of the different leaf resources by the invertebrate shredders. This corroborates the study by Villanueva et al. (2011), where they did not observe consumption of Sericostoma vittatum by an increase in carbon, nitrogen and phosphorus ingestion between the temperatures of $15^{\circ} \mathrm{C}$ and $20^{\circ} \mathrm{C}$, fed with three different diets (Alnus glutinosa, Eucalyptus globulus and Quercus robur). However, studies have reported that the efficiency in assimilating $\mathrm{N}, \mathrm{P}$ and $\mathrm{C}$ in detritivorous species may be simultaneously affected by the temperature and diet (Villanueva et al. 2011).

In the presence of carcass was observed the construction of casebuilding by Phylloicus sp., possibly due the chemical substances released from fish carcass could indicate the risk of predation. These can lead invertebrate to build shelters that ensured protection from predators. Litters of Talauma ovata and Richeria grandis were used frequently to build case, probably due its higher abundance, quality resources and faster losses of leaf mass in all treatments. This corroborates some studies that suggest that Phylloicus have preference for some plants species, where the leaf litter used to build case is very flexible and depends on its abundance in its habitats (Moretti et al. 2009, Hanna 1961, Otto \& Svensson 1980).

The risk of predation tends to result in physiological stress on preys, which consists in changes in neuroendocrine and biochemical processes, acceleration of metabolism, respiratory and cardiovascular rates and behavioral changes, so as to increase the survival of the species before life-threatening situations and to keep the physiological homeostasis (Wingfield \& Ramenofsky 1999). Other studies report that the increase in the temperature tends to generate an exponential increase in the metabolic rate (Brown et al. 2004). The presence of fish carcass was capable of increasing the consumption over Talauma ovata as compared to the experiment without carcass, in all temperatures, even in the presence of a second resource of good quality (Richeria grandis). This suggests that the risk of predation may be capable of generating a physiological stress in Phylloicus sp., stimulating these invertebrate to increase their shredding activity on high-quality litter that ensure an energy input more effectively and efficiently, mainly in intermediate temperatures $\left(26^{\circ} \mathrm{C}\right.$ and $\left.28^{\circ} \mathrm{C}\right)$.

\section{Experiment 1 (absence of fish carcass $) \times$ Experiment 2 (presence of fish carcass)}

In experiment 1 , the presence of only one stressing agent and a better quality resource allowed Inga larina to be explores with higher intensity, even with the increase in the temperature. However, the strong negative correlation of leaf mass loss of the species Inga laurina in relation to the temperature in the presence of fish carcass may be related to the increase in the physiological stress for shredder by increase in the temperature and risk of predation (stressor agents) (Wingfield \& Ramenofsky 1999, Brown et al. 2004). This may have accelerated the metabolism of these invertebrate, leading them to expand their shredding activity on the litters of better quality (Talauma ovata and Richeria grandis) and more abundant. Thus, this reduction in the exploration of Inga laurina, that contains a higher concentration of refractory compounds, with the increase in the temperature, may be a strategy to meet their energy need with higher efficiency and lower energy consumption.

\section{Conclusion}

Our results indicate that the Phylloicus sp. larvae present a higher shredding capacity on litters that contain lower percentage of structural (refractory) and secondary compounds, regardless of the temperature gradient. The presence of fish carcass is capable of simulating the risk of predation on Phylloicus sp. and accelerating the shredding behavior of this invertebrate on the better quality resources. This probably occurs to meet energy needs arising out of a probable state of stress or to build case that ensure higher protection and survival.

\section{Acknowledgements}

We are grateful to PROCAD-NF/CAPES (No. 173/2010), PELD/CNPq (No. 558233/2009-0), FAPEMIG (No. APQ-0027412), Graduate Program in Biological Sciences/Unimontes, and Scholarship of Graduation (PROIC/2012-Newly-Doutor/DPP) and founds of University of Brasília (DPP; No. 121366/2011) for the financial support. Also, the REUNI Program for offering a $\mathrm{PhD}$ Scholarship to Fernanda Navarro (No.07/2011). Finally, we would like to express our special gratitude to all evening students from the discipline Physical Environment and Ecosystems-2011.

\section{References}

AZEVEDO-PEREIRA, H., GONZÁLEZ, J. \& GRAÇA, M.A.S. 2006. Life history of Lepidostomahirtumin an Iberian stream and its role on organic matter processing. Hydrobiologia 559:183-192. http://dx.doi.org/10.1007/ s10750-005-1267-1

BÄRLOCHER, F. \& GRACA, M.A.S. 2005. Total phenolics. In Methods to Study Litter Decomposition: A Practical Guide (M.A.S. Graça, F. Bärlocher \& M.O. Gessner, eds.). Springer, Dordrecht, p.45-48. http:// dx.doi.org/10.1007/1-4020-3466-0_14

BOYERO, L., PEARSON, R.G., GESSNER, M.O., BARMUTA, L.A., FERREIRA, V., GRAÇA, M.A.S., DUDGEON, D., BOULTON, A.J., CALLISTO, M., CHAUVET, E., HELSON, J.E., BRUDER, A., ALBARIÑO, R.J., YULE, C.M., ARUNACHALAM, M., DAVIES, J.N., FIGUEROA, R., FLECKER, A.S., RAMÍREZ, A., DEATH, R.G., IWATA, T., MATHOOKO, J.M., MATHURIAU, C., GONCALVES, J.F., MORETTI, M.S., JINGGUT, T., LAMOTHE, S., M'ERIMBA, C., RATNARAJAH, L., SCHINDLER, M.H., CASTELA, J., BURIA, L.M., CORNEJO, A., VILLANUEVA, V.D. \& WEST, D.C. 2011. A global experiment suggests climate warming will not accelerate litter decomposition in streams but might reduce carbon sequestration. Ecol. Lett. 14:289-294. PMid:21299824. http://dx.doi.org/10.1111/j.14610248.2010.01578.x

BRÖNMARK, C. \& HANSSON, L.A. 2000. Chemical communication in aquatic systems: an introduction. Oikos, 88:103-109. http://dx.doi. org/10.1034/j.1600-0706.2000.880112.x

BROWN, J.H., GILLOLY, J.F., ALLEN, A.P., SAVAGE, V.M. \& WEST, G.B. 2004. Toward a metabolic theory of ecology. Ecology 85:1771-1789. http://dx.doi.org/10.1890/03-9000

CARPENTER, S.R. \& ADAMS, M.S. 1979. Effects of nutrients and temperature on decomposition of Myriophyllum spicatum L. in a hardwater eutrophic lake. Limnol. Oceanogr. 24:520-528. http://dx.doi. $\operatorname{org} / 10.4319 / 10.1979 .24 .3 .0520$

CHAPIN III, F.S., MATSON, P.A. \& MOONEY, H.A. 2002. Principles of Terrestrial Ecosystem Ecology. Springer Science, Business Media inc., p.472.

CHERGUI, H. \& PATTEE, E. 1990. The influence of season on the breakdown of submerged leaves. Arch. Hydrobiol. 120:1-12.

COLEY, P.D. \& AIDE, T.M. 1991.Comparison of herbivory and plant defense in temperate and tropical broad-leaved forests. In: Plant-Animal Interactions: Evolutionary Ecology in Tropical and Temperate Regions (P.W. Price, T.M. Lewinsohn, G.W. Fernandes \& W.W. Benson, eds.). Wiley, New York, p.25-49.

GESSNER, M.O. \& CHAUVET, E. 1994. lmportance of stream microfungiin controlling breakdown rates of leaf litter. Ecology 75:1807-1817. http:// dx.doi.org/10.2307/1939639

GESSNER, M.O. \&CHAUVET, E. 2002. A case for using litter breakdown to asses functional stream integrity. Ecol. Appl. 12:498-510. http://dx.doi. org/10.1890/1051-0761(2002)012[0498:ACFULB]2.0.CO;2

GESSNER, M.O., SWAN, C.M., DANG, C.K., MCKIE, B.G., BARDGETT, R.D., WALL, D.H. \& HATTENSCHWILER, S. 2010. Diversity meets 
decomposition. Trends Ecol. Evol. 25:372-380. PMid:20189677. http:// dx.doi.org/10.1016/j.tree.2010.01.010

GESSNER, M.O. 2005. Proximate Lignin and Cellulose. In Methods to Study Litter Decomposition: A Practical Guide (M.A.S. Graça, F. Bärlocher \& M.O. Gessner, eds.). Springer, Dordrecht, p.115-120. http://dx.doi. org/10.1007/1-4020-3466-0_17

GONÇALVES JUNIOR, J.F., GRAÇA, M.A.S. \& CALLISTO, M. 2006. Leaf-litter breakdown in 3 streams in temperate, Mediterranean, and tropical Cerrado climates. J. N. Am. Benthol. Soc.25:344-355. http:// dx.doi.org/10.1899/0887-3593(2006)25[344:LBISIT]2.0.CO;2

GONÇALVES JUNIOR, J.F., REZENDE, R.S., FRANÇA, J. \& CALLISTO, M. 2012. Invertebrate colonisation during leaf processing of native, exotic and artificial detritus in a tropical stream. Mar. Freshwater. Res. 63:428-439. http://dx.doi.org/10.1071/MF11172

GONZÁLEZ, J.M. \& GRAÇA. M.A.S. 2003. Conversion of leaf litter to secondary production by a shredding caddis-fly. Freshwater Biol. 48:1578-1592. http://dx.doi.org/10.1046/j.1365-2427.2003.01110.x

GRAÇA, M.A.S., CRESSA, C., GESSNER, M.A., FEIO, M.J., CALLIES, K.A. \& BARRIOS, C. 2001. Food quality, feeding preferences, survival and growth of shredders from temperate and tropical streams. Freshwater Biol. 46:947-957. http://dx.doi.org/10.1046/j.1365-2427.2001.00729.x

GRAÇA, M.A.S. \&ZIMMER, M. 2005. Leaf toughness. In Methods to Study Litter Decomposition: A Practical Guide (M.A.S. Graça, F. Bärlocher \& M.O. Gessner, eds.). Springer, Dordrecht, p.109-113. http://dx.doi. org/10.1007/1-4020-3466-0 18

HAGEN, E.M., WEBSTER, J.R. \& BENFIELD, E.F. 2006. Are Leaf Breakdown Rates a Useful Measure of Stream Integrity along an Agricultural Landuse Gradient? J. N. Am. Benthol. Soc. 25(2):330-343. http://dx.doi.org/10.1899/0887-3593(2006)25[330:ALBRAU]2.0.CO;2

HANNA, H.M. 1961. Selection of materials for case-building larvae of caddis flies (Trichoptera). P. Roy. Soc. Lond. B Bio. 36:37-47.

HOUGHTON, J.T., DING, Y., GRIGGS, D.J., NOGUER, M., VAN DER LINDEN, P.J. \& XIAOSU, D. 2001. Climate Change 2001. The Scientific Basis Contribution of Working Group I to the Third Assessment Report of the Intergovernmental Panel on Climate Change - IPCC (Eds.) University Press, Cambridge, p.944.

HUAMANTINCO, A.A., DUMAS, L.L. \& NESSIMIAN, J.L. 2005. Description of larva and pupa of Phylloicusabdominalis Ulmer, 1905 (Trichoptera: Calamoceratidae). Zootaxa 1039:19-26.

INTERGOVERNMENTAL PANEL ON CLIMATE CHANGE - IPCC Climate Change. 2007. The Physical Science Basis. Contribution of Working Group I to the Fourth Assessment Report of the Intergovernmental Panel on Climate Change (Solomon, S., Qin, D., Manning, M., Chen, Z., Marquis, M., Averyt, K.B.,Tignor, M. and Miller, H.L., eds.). Cambridge University Press, Cambridge, UK.

KONISHI, M., NAKANO, S. \& IWATA, T. 2001. Trophic cascading effects of predatory fish on leaf litter processing in a Japanese stream. Ecol. Res.16:415-422. http://dx.doi.org/10.1046/j.1440-1703.2001.00406.x

LEROY, C.J. \& MARKS, J.C. 2006. Litter quality, stream characteristics and litter diversity influence decomposition rates and macroinvertebrates. Freshwater Biol. 51:605-617. http://dx.doi.org/10.1111/j.13652427.2006.01512.x

LISKI, J., NISSINEN, A., ERHARD, M. \& TASKINEN, O. 2003. Climatic effects on litter decomposition from arctic tundra to tropical rainforest. Global Change Biol. 9:575-584. http://dx.doi.org/10.1046/j.13652486.2003.00605.x

MASSEY JUNIOR, F.J. 1951. The Kolmogorov-Smirnov test for goodness of fit. J. Am. Stat. Assoc. 46:68-78. http://dx.doi.org/10.1080/0162145 9.1951.10500769

MIYASHITA, T. \& NIWA, S. 2006. A test for top-down cascade in a detritusbased food web by litter-dwelling web spiders. Ecol. Res. 21:611-615. http://dx.doi.org/10.1007/s11284-006-0155-0

MOONEY, H., LARIGAUDERIE, A., CESARIO, M., ELMQUIST, T., HOEGH-GULDBERG, O., LAVOREL, S., MACE, G. M., PALMER, M., SCHOLES, R. \& YAHARA, T. 2009. Biodiversity, climate change, and ecosystem services. Curr. Opin. Environ. Sustainab. 1:46-54. http:// dx.doi.org/10.1016/j.cosust.2009.07.006
MORETTI, M.S. 2005. Decomposição de detritos foliares e sua colonização por invertebrados aquáticos em dois córregos na Cadeia do Espinhaço (MG). Dissertação de Mestrado, Universidade de Minas Gerais, Belo Horizonte.

MORETTI, M.S., LOYOLA, R.D., BECKER, B. \& CALLISTO, M. 2009. Leaf abundance and phenolic concentrations codetermine the selection of case-building materials by Phylloicus $s p$. (Trichoptera, Calamoceratidae). Hydrobiologia 630(1):199-206. http://dx.doi.org/10.1007/s10750-0099792-y

OSTROFSKY, M.L. 1997. Relationship between chemical characteristics of autumn-shed leaves and aquatic processing rates. J. N. Am. Benthol. Soc. 16:750-759. http://dx.doi.org/10.2307/1468168

OTTO, C. \& SVENSSON, B.S. 1980.The significance of case material selection for the survival of caddis larvae. J Anim. Ecol. 49:855-865. http://dx.doi.org/10.2307/4231

PRATHER, A.L. 2003. Revision of the Neotropicalcaddisfly genus Phylloicus(Trichoptera: Calamoceratidae). Zootaxa 275:1-214.

PRESS, W.H., TEUKOLSKY, S.A., VETTERLING, W.T. \& FLANNERY, B.P. 1992. Numerical Recipes in C. Cambridge University Press.

RATNARAJAH, L. \& BARMUTA, L.A. 2009. The effects of leaf toughness on feeding preference by two Tasmanian shredders. Hydrobiologia 636(1):173-178. http://dx.doi.org/10.1007/s10750-009-9946-y

RUETZ, C.R., NEWMAN, R.M. \& VONDRACEK, B. 2002. Top-down control in a detritus-based food web: fish, shredders, and leaf breakdown. Oecologia 132:307-315. http://dx.doi.org/10.1007/s00442-002-0953-1

RUETZ III, C.R., BREEN, M.J. \& VANHAITSMA, D.L. 2006.Habitat structure and fish predation: effects on invertebrate colonisation and breakdown of stream leaf packs. Freshwater Biol. 51(5):797-806. http:// dx.doi.org/10.1111/j.1365-2427.2006.01525.x

RUTHER, J., MEINERS, T. \& STEIDLE, J.L.M. 2002. Rich in phenomenalacking in terms. A classification of kairomones. Chemoecology 12:161167. http://dx.doi.org/10.1007/PL00012664

SUBERKROPP, K. \& CHAUVET, E. 1995. Regulation of leaf breakdown by fungi in streams: influences of water chemistry. Ecology 76:1433-1445. http://dx.doi.org/10.2307/1938146

TABACCHI, E., CORRE, L.D.L., HAUER, R., PINAY, G., PLANTYTABACCHI, A.M. \& WISSMAR, R.C. 1998. Development, maintenance and role of riparian vegetation in the river landscape. Freshwater Biol. 40:497-516. http://dx.doi.org/10.1046/j.1365-2427.1998.00381.x

VILLANUEVA, V.D., ALBARIÑO, R. \& CANHOTO, C. 2011. Detritivores feeding on poor quality food are more sensitive to increased temperatures. Hydrobiologia 678:155-165. http://dx.doi.org/10.1007/s10750-0110837-7

WALLACE, J.B., EGGERT, S.L., MEYER, J.L. \& WEBSTER, J.R. 1997. Multiple trophic levels of a forest stream linked to terrestrial litter inputs. Science 277:102-104. http://dx.doi.org/10.1126/science.277.5322.102

WOODS, H.A., MAKINO, W., COTNER, J.B., HOBBIE, S.E., HARRISON, J.F., ACHARYA, K. \& ELSER, J.J. 2003. Temperature and the chemical composition of poikilothermic organisms. Funct. Ecol. 17:237-245. http:// dx.doi.org/10.1046/j.1365-2435.2003.00724.x

WANTZEN, K.M. \& WAGNER, R. 2006. Detritus processing by invertebrate shredders: a neotropical-temperate comparison. J. N. Am. Benthol. Soc. 25:214-230. http://dx.doi.org/10.1899/0887-3593(2006)25[216:DPBI $\mathrm{SA}] 2.0 . \mathrm{CO} ; 2$

WIGGINS, G.B. 1996. Larvae of North American Caddisfly Genera (Trichoptera). 2nd ed. University of Toronto Press, Ontario.

WINGFIELD, J.C. \& RAMENOFSKY, M. 1999. Hormones and the behavioral ecology of stress. In Stress physiology in animals (P.H.M. Baum, ed.). Sheffield Academic, Sheffield, p.1-51.

WRIGHT, M.S. \& COVICH, A.P. 2005. The effect of macroinvertebrate exclusion on leaf breakdown rates in a tropical headwater stream. Biotropica. 37:403-408. http://dx.doi.org/10.1111/j.1744-7429.2005.00053.x

ZAR, J.H. 1996. Biostatistical analysis. Prentice-Hall, Upper Saddle River, New Jersey. 